\title{
Open Government Data: Facilitating and Motivating Factors for Coping with Potential Barriers in the Brazilian Context
}

\author{
Claudio Sonaglio Albano ${ }^{1}$ and Nicolau Reinhard ${ }^{2}$ \\ ${ }^{1}$ Unipampa, Federal University of Pampa, Bagé, Brazil \\ claudio.albano@unipampa.edu.br \\ ${ }^{2}$ School of Economics, Business and Accounting, Business Department, \\ University of Sao Paulo, Brazil \\ reinhardeusp.br
}

\begin{abstract}
The use of Open Government Data (OGD) involves multiple activities developed by networks of users with different capacities and goals, along a value chain. These users, and also government agents supplying OGD recognize benefits, motivations, barriers, facilitating and inhibiting factors in the process. This paper surveyed the perceptions of Brazilian OGD users and government agents, in order to provide information for the improvement of OGD supply and use.
\end{abstract}

Keywords: open government data, benefits and barriers, facilitating and motivating factors.

\section{Introduction and Research Question}

According to the [21], open government data (OGD) is the publication and dissemination of public sector information on the Internet, shared in a logically understandable format, to allow its reuse in machine-readable form.

The potential advantages arising from the participation in OGD initiatives, have to be seen in conjunction with the difficulties for the realization of these benefits. According to [17], it should not be expected that simply by opening their data, governments will be able to generate the expected benefits for administrations and society.

The success of OGD initiatives requires an extensive interaction between governments and society $[5,7,18]$. According to these authors, governments are not able to follow technology changes with the desired agility, due to excessive bureaucracy and regulations. The private sector or non-profit organizations manage to be more competent to deliver information to citizens and enable them to better use the public information available.

The challenges in the implementation of OGD projects are due to the multiple interactions among players, information flows, technologies and the interests involved in these initiatives, resulting in a dynamic process of interactions between 
governments and society, building networks between the organizations. According to $[9,10]$, this understanding is not yet fully available in guides, tools, techniques and theories to deal with open government data, motivating the present study's research question: Can a greater understanding of users' network and the motivating and facilitating factors to cope with the potential barriers and inhibiting factors, seeking potential benefits and advantages, help public administrators to achieve better results with their OGD projects?

The survey was conducted with Brazilian users and government suppliers of OGD and is aimed at providing a contribution to public administrators by enabling a greater understanding of the factors that may support their OGD projects. It must be noted that Brazil, despite the enacted legislation mandating OGD at all levels of government, is still at an early stage of OGD supply and use.

\section{$2 \quad$ Literature Review}

\subsection{Potential Benefits and Advantages}

According to [13] the their first stage of ODG maturity, the goal of governments initiatives is to allow transparency and control of government actions. Society is then able to create products and services, useful both for society and governments, with the possibility of generating new economic activities, among other social benefits and advantages.

[12] classifies these possible benefits into three major groups: political and social, economic, and technical and operational. Political and social benefits are related to issues involving transparency, democracy, promotion of citizenship, among others.Promoting a greater stimulus to innovation, the ability to generate new products and services, the integration between government and society, among others, are associated with economic benefits. The possibility for governments and society to work in cooperation to improve processes, through the use of knowledge (and collective capabilities) is related to potential operational and technical benefits and advantages.

According to [20] some countries have progressed beyond the mere access to data, where the Open Datahas shown that it not only produces significant changes in the public sector, but it generates synergies in innovation and entrepreneurship. In the Brazilian context, authors [4], argue as key benefits that can be achieved through OGD projects: greater promotion of citizenship, ability to develop new products and services from governments to society, greater efficiency for governments, among others.

\subsection{Potential Barriers and Inhibiting Factors}

There are, however, challenges, barriers and inhibiting factors to OGD initiatives. [6] suggests as challenges: technical problems in information processing, information collected in different ways and for different purposes, work overload to make this 
information available, heterogeneity of users and their inability to work with the information, among others. Other factors that may be regarded as potential barriers and inhibiting factors involve the "understanding" of the data by society (discussed in the topic - quality and usability of the content available, in addition to structural and technological issues of public organizations [19, 23].

[12] classifies the potential barriers and inhibiting factors into six major groups, which are as follows:institutional, complexity of the tasks, use and participation, legislation, quality of information and techniques.Institutional factors are associated with cultural and structural issues of public entities.Likewise, Government's internal problems, but related to technical issues, are associated with the complexity of the task.

The uneven motivation of society to participate in OGD initiatives, as well as their capacity to use these data are related to the factor use and participation. There are also legal issues on which information may be made available, as well as their use. The quality of information is related not only to the quality of the information available, but also to the relevance of the information to its users, and finally, technical issues are related to the information technology tools that support the provision of information.

[4] in their respective studies developed in the Brazilian context, identify as major barriers and inhibiting factors in the context of OGD projects: the low capacity of society to access and use the information; this fact generates lack of interest and low interaction.Technical issues, involving the quality and format of the information available, and finally, aspects related to legislation.

\subsection{Facilitating and Motivating Factors - Interorganizational Networks}

Networking is essential for an organization to be able to integrate the new requirements in a scenario marked by the importance of technology, information and knowledge. An OGD project is established by government, but it may involve several entities of a single government or several governments, such as websites that accept data from other governments. Analysing the relationships between organizations is a complex task, especially in environments of heterogeneous relationships (that is, involving public and private organizations).

The complexity is further enhancedwhen each participant organization has diverse interests and bonds and is able to simultaneously participate in several networks. It is important to identify which factors sustain the relationships established in interorganizational networks. In this sense basically, two main aspects are seen as able to sustain these relationships, the motivating aspects and the facilitating aspects. According to [16] the motivating aspects refer to needs of organizations to participate in networks to achieve commercial advantages, legal advantages, or advantages from other sources. Other motivating aspects include: the power that an organization has over the others; the possible gains when cooperating with third parties; obtaining legitimacy and stability through the established partnerships. 
For $[3,8,22]$, the facilitating factors are related to the governance that can be sought on networking, the search for reliability (especially in unstable environments), and establishing a greater reputation, are examples of facilitating factors. Obtaining advantages through the exchange of information, as well as the investments made by an organization (through training, tools, etc.) can help organizations to establish relationships in complex environments. Concepts of the Gift Economy, like reputation, reciprocity, communities, etc., can be recognized in the motivations of OGD users and should be considered by governments to promote OGD $[1,14]$.

\section{Open Government Data in Brazil}

In 2011, Brazil became a member of the Open Government Partnership (OGP), making a commitment to encourage and promote public policies of transparency and publish data in open format. As a result of this commitment, on November 18, 2011, the Law No. 12527 was enacted, which entered into force on May 16, 2012, regulating the constitutional right for citizens to have access to government data at all levels. Special situations had already been regulated by laws and decrees between 2009 and 2010. The effective implementation of these regulations, however, is still a challenge, specially at the municipal level, as demonstrated by the nationwide survey on Electronic Government 2010 [2]. Government initiatives include the 2012 conference for open data, organized by the Office of the Comptroller General (CGU), who is also responsible for monitoring the compliance with the law.

\section{Reference Model}

The paper's research questions are: a) identify the benefits expected by users and government from the use of open government data (OGD), and its barriers and inhibiting factors; b) identify the network of players (individuals and organizations), their roles and motivations in the use of OGD. [12] provided the concepts for the OGD benefits and barriers. The resulting categories for analysis are displayed in Table 1 .

Table 1. Categories defined for data analysis

\begin{tabular}{|l|l|}
\hline \multicolumn{1}{|c|}{ Category } & \multicolumn{1}{|c|}{ Category characteristics } \\
\hline $\begin{array}{l}\text { Benefits and advantages } \\
\text { Source: [12] Topic }-2.1\end{array}$ & Items:political, social, economic and operational or technical. \\
\hline $\begin{array}{l}\text { Barriers and inhibiting } \\
\text { factors.Source: [12] Topic }-2.2\end{array}$ & $\begin{array}{l}\text { Items:Institutional, complexities of the task, use and } \\
\text { participation, legislation, quality of information and techniques. }\end{array}$ \\
\hline $\begin{array}{l}\text { Facilitating and motivating } \\
\text { factors.Source: Interorganizational } \\
\text { Networks Topic }-2.3\end{array}$ & $\begin{array}{l}\text { OGD activities.References or citations to the activities and their } \\
\text { goals. }\end{array}$ \\
\hline
\end{tabular}


[11] provided the conceptualization of primary and support activities for the open data value chain, with Organizational Network Theory providing the rationality of members participation in the network [16] and the reference network model is displayed in Figure 1.

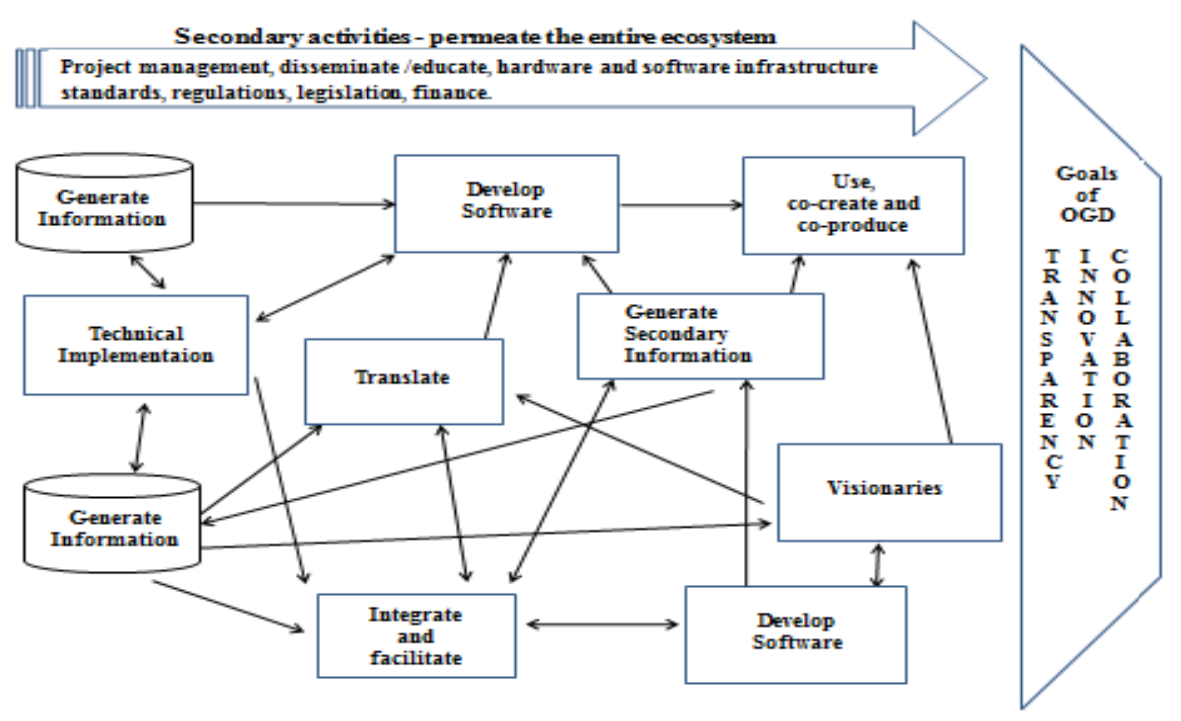

Fig. 1. Reference Network Model: Authors of work

\section{$5 \quad$ Methodological Procedures}

The research used an interpretative approach, based on qualitiative data from surveys of a convenience sample. Data collection was performed in two stages. First, we conducted semi-structured interviews, consisting of questions regarding the respondents OGD activities, expected benefits, facilitators and motivators, barriers and inhibiting factors, with a sample consisting of authors' contacts from events related to the subject, internet directories and search in websites for open government data projects, resulting in: seven government representatives (employees of government entities/agencies with open data projects); five developers (professionals working with software based on open data); two professors from public universities; one investigative journalist and three representatives of civil society organizations, totaling 18 respondents.

These respondents indicated the sample for the second data collection (open interviews): a journalist; one member of each: a state government; a municipal government (also a journalist); a non-governmental organization with mainly technical activity; a private for-profit organization that develops tools for the 
provision of open data; two non-governmental and non-profit organizations that operate by integrating other organizations; a federal government agency; a private forprofit company that operates in healthcare with open data, and alsotwo scholars and a software developer (who develops applications based on open data).

The research also included documentary:Brazilian legislation on the provision of public data, in particular, the Law No. 12527 (Access to Information Act - AIA), regulations and decrees of the federal government that formalized the National Infrastructure for Open Data (INDA), minutes and action plans of INDA. Content analysis was used to analyse the transcriptions of interviews and documents, using an a priori categorization of concepts.

\section{$6 \quad$ Results and Discussions}

First, we present the potential benefits and advantages that can be achieved in OGD initiatives, as perceived by the respondents (members of governments and society), followed by the barriers and inhibiting factors. The benefits and advantages, as well as the barriers and inhibiting factors are separated according to the interviews and documents, following the opinions of members of governments and society, as further analyses will make reference to these two groups separately. The survey's results indicate that the respondents views correspond to the very initial stage of Open Government of [13]. Their expectations of OGD provided by public administration are limited to the first stage of [13].

Our research aimed at a) verifying the possibility of a network of nongovernmental agents also realizing the functionalities of stages 2 and 3 [13], depending on the public agents providing the data in a form that allows those agents to select integrate and recombine the data according to their specific needs; and $b$ ) Identifying required infrastructure (legal, technical, etc.) to support these network activities.

Engaging users in these activities would, of course, not preclude public agents from also performing these activities. Non-government agents, however, could be more motivated to do it, since they would perceive more directly the value of the activity, therefore increasing the sustainability of the value chain.

As an example of government action, one local government agency in our sample provides the users with private working spaces, where they can store their queries and data sets. This space, however, in order to benefit from the network, would have to allow also importing and combining data from external sources, providing also analysis and display tools and allow sharing and collaboration among different users.

This would be particularly important for the use of statistical, georeferenced and text data that may require specialized resources for analysis and manipulation, differing from the use of individual transaction data. This is also a response to the "Specific Assets" facilitating factor, the most cited. (INDA as a framework was heavily cited). 


\subsection{Benefits and Advantages, Barriers and Inhibiting Factors}

This section firstly presents the results and analyses of the benefits and advantages found for governments. Political and social factors are mentioned as major benefits. Among these factors, transparency and processes that generate greater integration and reliability between government and society stand out. The second group of potential benefits and advantages refers to operational and technical aspects, which include the optimization of internal processes and the greater possibility to use data through the collaboration of various stakeholders, even among several governments. Possible benefits and economic advantages received little emphasis, but respondents stated that they may be achieved through a greater collaboration and incentive to innovation.

For society, political and social factors are also mentioned as possible benefits and advantages, including issues related to greater transparency and citizenship. Operational and technical factors are mentioned, including the possibility of offering new products and services to society and to generate greater integration between society and government. New functionalities with greater provision of information allow the development of new capabilities, especially through the networked collaboration between different segments of society, with a reference to the use of collective knowledge as a source of benefits. For government, benefits and economic advantages are mentioned with lower frequency.

The major inhibiting factors and barriers for governments are related to technical factors, especially the format and quality of information made available. Institutional factors, such as structural and political issues are the second group of factors mentioned as potential barriers. Legislation comes shortly after, indicating the lack of clarity about privacy as the most mentioned factor. Finally, mentioned as possible barriers within governments are issues related to the low interest of civil servants to cooperate with these initiatives.

Members of society, similarly to government members, understand the same technical issues as the biggest barriers, mainly, the format and quality of information. However, the lack of interest in the use of the information provided is mentioned as the second biggest barrier among the members of society. Issues related to legislation are mentioned as the third group of barriers, once again the clarity about which information can be made available is mentioned with emphasis.

\subsection{Facilitating and Motivating Factors}

The first group of respondents mentioned as facilitating and motivating factorsthe network of other players (or organizations).In the interviews of the second round of interviews, the researchers aimed a identifying the activities of each user category. Table 2 displays the answers grouped according to the occupations or backgrounds of the respondents. 
Table 2. Facilitating and Motivating Factors (I)

\begin{tabular}{|c|c|c|}
\hline $\begin{array}{c}\text { Players and } \\
\text { organizations }\end{array}$ & Activities developed & Goals \\
\hline Journalists & $\begin{array}{l}\text { Disseminate information among their peers and society in } \\
\text { general, train other colleagues (teaching courses) and } \\
\text { supervise the compliance with the LAI, in addition to } \\
\text { supporting non-governmental entities (with technological } \\
\text { activity) that operate with the subject.Encourage the } \\
\text { publication of open data and "evangelize" society on OGD. }\end{array}$ & $\begin{array}{l}\text { Generate a greater } \\
\text { demand for OGD }\end{array}$ \\
\hline $\begin{array}{l}\text { Public } \\
\text { Servants }\end{array}$ & $\begin{array}{l}\text { Collect data among the various entities of their agency for } \\
\text { publication.There are basically two data } \\
\text { sources:dataconsidered of interest by internal } \\
\text { governmetmembers or that have been demanded by } \\
\text { society. They work along with governmental organizations } \\
\text { formally to regulate the OGD operations of other } \\
\text { organizations.Performtechnical activities to enable the } \\
\text { publication of these data. }\end{array}$ & Make data available \\
\hline $\begin{array}{l}\text { Software } \\
\text { developers }\end{array}$ & $\begin{array}{l}\text { Work in software development through projects and events } \\
\text { called Hackatons.At these events participants develop short } \\
\text { projects. This action can be casual, highly driven by the } \\
\text { occurrence of these events. }\end{array}$ & $\begin{array}{l}\text { Develop } \\
\text { applications based } \\
\text { on OGD }\end{array}$ \\
\hline
\end{tabular}

Table 2a. Facilitating and Motivating Factors (II)

\begin{tabular}{|c|c|c|}
\hline Scholars & $\begin{array}{l}\text { Their activities are motivated by } \\
\text { their interest in some specific } \\
\text { area (health, budget, etc.), and } \\
\text { they seek to have these data used } \\
\text { by society. }\end{array}$ & $\begin{array}{l}\text { Promote greater interest in the } \\
\text { subject. }\end{array}$ \\
\hline Players and organizations & Activities developed & Goals \\
\hline $\begin{array}{l}\text { Non-governmental } \\
\text { organizations (for-profit) with } \\
\text { technical expertise. }\end{array}$ & $\begin{array}{l}\text { Develop technical tools to } \\
\text { facilitate (support) the supply of } \\
\text { data in an open format. }\end{array}$ & $\begin{array}{l}\text { Offer products and technical } \\
\text { tools. }\end{array}$ \\
\hline $\begin{array}{l}\text { Non-governmental } \\
\text { organizations (non-profit) } \\
\text { without technical expertise. }\end{array}$ & $\begin{array}{l}\text { Organize the OGD content to be } \\
\text { published, supportorganizations } \\
\text { in their search for financial and } \\
\text { technical resources for OGD } \\
\text { activities. }\end{array}$ & $\begin{array}{l}\text { Promote the participation of } \\
\text { civil society and government } \\
\text { entities on the subject. }\end{array}$ \\
\hline $\begin{array}{l}\text { Nongovernmental organizations } \\
\text { (for-profit) without technical } \\
\text { expertise. }\end{array}$ & $\begin{array}{l}\text { Acts as intermediary between } \\
\text { government and society, helping } \\
\text { citizens to find and access } \\
\text { specific government services }\end{array}$ & $\begin{array}{l}\text { Add products and services to } \\
\text { their portfolio of solutions. }\end{array}$ \\
\hline $\begin{array}{l}\text { State organization with technical } \\
\text { expertise }\end{array}$ & $\begin{array}{l}\text { Offer access to raw data and } \\
\text { elaborated information. Provide } \\
\text { metadata, tools for query, } \\
\text { analysis and presentation of data. } \\
\text { Can act in partnership with other } \\
\text { organizations. }\end{array}$ & $\begin{array}{l}\text { Produce and disseminate } \\
\text { socioeconomic } \\
\text { demographic statistics and } \\
\text { analyzes }\end{array}$ \\
\hline
\end{tabular}


Table 2a. (continued)

\begin{tabular}{|l|l|l|}
\hline $\begin{array}{l}\text { International organization } \\
\text { operating in Internet on the } \\
\text { subject }\end{array}$ & $\begin{array}{l}\text { Has strong international presence } \\
\text { in the definition of rules and } \\
\text { standards for the Internet, having } \\
\text { also worked heavily in the } \\
\text { Brazilian ecosystem of open data } \\
\text { and OGD. Is active in Brazil in the } \\
\text { standardizing activities, promotion } \\
\text { and advocacy of OGD, producing } \\
\text { publications and events. }\end{array}$ & $\begin{array}{l}\text { OGD Promotion and advocacy, } \\
\text { contribute to normatization }\end{array}$ \\
\hline $\begin{array}{l}\text { Non-governmental } \\
\text { organizations (for-profit) with } \\
\text { technical expertise. }\end{array}$ & $\begin{array}{l}\text { Develop technical tools to } \\
\text { facilitate (support) the supply of } \\
\text { data in an open format. }\end{array}$ & $\begin{array}{l}\text { Offer products and technical } \\
\text { tools. }\end{array}$ \\
\hline $\begin{array}{l}\text { Non-governmental } \\
\text { organizations (for-profit) with } \\
\text { technical expertise. }\end{array}$ & $\begin{array}{l}\text { Develop technical tools to } \\
\text { facilitate (support) the supply of } \\
\text { data in an open format. }\end{array}$ & $\begin{array}{l}\text { Offer products and technical } \\
\text { tools. }\end{array}$ \\
\hline
\end{tabular}

\subsection{Facilitating and Motivating Factors for Coping with Potential Barriers and Inhibiting Factors}

In Table 3, the barriers are confronted with the respective facilitating and motivating factors, which can support the reduction or even the elimination of these barriers.

Table 4 shows how the facilitating and motivating factors confronting the barriers can provide better conditions for the benefits and advantages to be effectively achieved.

Table 3. Barriers, facilitating and motivating factors

\begin{tabular}{|l|l|l|}
\hline Barrier & Who faces it? & Facilitating and motivating factors. \\
\hline Technical factors & Government & $\begin{array}{l}\text { Civil servants, whose job is to develop activities that } \\
\text { can technically facilitate the access to information; } \\
\text { Software developers demand enhanced quality } \\
\text { information for their applications } \\
\text { Nongovernmental organizations (for-profit) with } \\
\text { technical expertise, developinghigh quality applications } \\
\text { (platforms) } \\
\text { International organization promoting the dissemination } \\
\text { of ODG use and standards. }\end{array}$ \\
\hline Institutional factors & Society & $\begin{array}{l}\text { Journalists, scholars and the international organization } \\
\text { working with OGD. They can pressuregovernmentfor } \\
\text { increased effort, agility, quality in } \\
\text { informationprovision. }\end{array}$ \\
\hline Legislation & Governments & $\begin{array}{l}\text { Journalists, as watchdogs of government compliance } \\
\text { with legislation and promoting society's interest in } \\
\text { OGD. Scholars, civil servants contribute to } \\
\text { improvement and solution of problems with the } \\
\text { legislation. }\end{array}$ \\
\hline $\begin{array}{l}\text { Use and } \\
\text { participation }\end{array}$ & Society & $\begin{array}{l}\text { Journalists, scholars, non-governmental organizations } \\
\text { (non-profit), international organization working on the } \\
\text { dissemination and increasing society awareness and } \\
\text { interest in OGD. }\end{array}$ \\
\hline
\end{tabular}


Table 4. Benefits $X$ facilitating and motivating factors

\begin{tabular}{|c|c|c|}
\hline Benefit & Who seeks it? & Facilitating and motivating factors. \\
\hline $\begin{array}{l}\text { Political and social } \\
\text { Transparency, } \\
\text { integration and } \\
\text { reliability }\end{array}$ & Government & \multirow{2}{*}{$\begin{array}{l}\text { Journalists, scholars and non-profit non-governmental } \\
\text { organizations, promoting the subject tosociety.Mayhelp } \\
\text { in the use of data by improving the interaction between } \\
\text { government and society. } \\
\text { Scholars, by conducting research (and studies) in } \\
\text { specified areas also contribute to the achievement of } \\
\text { these advantages. }\end{array}$} \\
\hline $\begin{array}{l}\text { Political and social } \\
\text { Transparency and } \\
\text { greater exercise of } \\
\text { citizenship }\end{array}$ & Society & \\
\hline $\begin{array}{l}\text { Operational and } \\
\text { technicalOptimization of } \\
\text { internal processes and } \\
\text { increased use of data }\end{array}$ & Government & $\begin{array}{l}\text { Public servants, by promoting greater use of the data, } \\
\text { with higher quality, provide greater collaboration } \\
\text { between governments. }\end{array}$ \\
\hline $\begin{array}{l}\text { Operational and } \\
\text { technicalSupply of new } \\
\text { products and services. }\end{array}$ & Society & $\begin{array}{l}\text { Software developers and organizations that develop } \\
\text { tools for the provision of data, by creating the technical } \\
\text { conditions for these activities.Journalists, scholars and } \\
\text { nongovernmental non-profit organizations without } \\
\text { technical expertise, by suggesting possible niches or } \\
\text { opportunities for the development of new products and } \\
\text { services. }\end{array}$ \\
\hline $\begin{array}{l}\text { Economic } \\
\text { Greater collaboration }\end{array}$ & Government & $\begin{array}{l}\text { Public servants, by disseminating the subject internally, } \\
\text { are able to allow greater collaboration, and possibly the } \\
\text { development of our products and services to } \\
\text { governments. }\end{array}$ \\
\hline $\begin{array}{l}\text { Economic } \\
\text { use of collective } \\
\text { knowledge }\end{array}$ & Society & $\begin{array}{l}\text { All players (and organizations) by integrating their } \\
\text { activities and objectives. }\end{array}$ \\
\hline
\end{tabular}

Based on tables 3 and 4, it is possible to see how the players and organizations, mentioned as facilitating and motivating factors, through their activities, may face the aforementioned barriers and how they can contribute to the benefits (also mentioned by the respondents) to be achieved.

There are some players, such as journalists and scholars, who clearly have activities aimed at fostering greater activities from this context, because they seek to monitor the information available and verify their usefulness and importance to society. These activities contribute to the dissemination of the subject, and it could generate a greater interest from society on the subject, so that society can then require higher quality from governments when undertaking these initiatives, mitigating some barriers and enabling some benefits.

Other players, such as developers, public servants, organizations of society perform activities with technical bias. Barriers related to technical issues were the most cited by the respondents (between governments and society), so the presence of these players is important as they can require from the governments the provision of information with higher quality or develop products that support this activity.

Finally, organizations of society, non-profit and with no technical purposes, may indicate to the players (with technical expertise), being supported by journalists and scholars, possible niches of operation based on OGD. This activity may impact the context, causing a greater interest in the use of this information. 


\section{$7 \quad$ Final Considerations}

One result of the study is the confirmation by the Brazilian study of previous studies [12] regarding the benefits and advantages expected from OGD initiatives. Respondents perceive OGD as important to promote greater government efficiency and develop citizenship. Barriers are related to technical aspects (quality and format of information), legal issues and the still reduced interest of society in the subject.

A contribution of our paper is the recognition by the players of the importance of the network of users to facilitate and motivate OGD use. Concepts from Interorganizational Network Theory are helpful in systematizing these perceptions, but also, onn its more prescriptive side to guide government agents in its participation and support of these networks.

The main contribution of this study, especially for the Brazilian context, is to identify the facilitating and motivating factors, as a way to cope with the potential barriers.Players and organizations identifiedother players and organizations as possible facilitating and motivating factors, enabling a greater and better participation of everyone.

The results of the study may help governments to develop OGD initiatives with greater effectiveness, since by being awareofthe factors that can help coping with the barriers and inhibiting factors, they will beable to formulate strategies to integrate them into their initiatives, aiming atachieving greater and better results. Among these strategies, the integration of these facilitating and motivating factors in their initiatives should surely be included, thus providing better conditions for the development of their activities and consequently that all participants of these initiatives are able to achieve better results.

To Future Research, the OGD user network should, by its nature, be very dynamic and global. Our survey did not consider the business use of OGD, that should involve different networks, value chains and user motivations, therefore requiring a possibly different research approach. The importance of this research is increased by the economic potential of OGD use by companies [15].

\section{References}

1. Benkler, Y.: The Wealth of Networks (2006), http: //www.benkler.org/Benkler_Wealth_of_Networks.pdf

2. CGI. Brazilian Internet Steering Committee, Survey on the use of Information and Communication Technologies in Brazil ICT Electronic Government 2010 (2011)

3. Cox, A.: The art of the possible: relationship management in power regimes and supply chain. International Journal of Supply Chain Management 9(5), 346-356 (2004)

4. Craveiro, G., Santana, M., Albuquerque, J.P.: Assessing Open Government Budgetary Data in Brazil. In: ICDS 2013, The Seventh International Conference on Digital Society (2013)

5. Davies, T.G., Bawa, Z.A.: The Promises and Perils of Open Government Data (OGD). Special Issue: Community Informatics and Open Government Data 8(2) (2012), Disponível em: http: / / ci-journal . net/index.php/ciej/issue/view/41 (access ins May 2012) 
6. Dawes, S.S., Helbig, N.: Information strategies for open government: Challenges and prospects for deriving public value from government transparency. In: Wimmer, M.A., Chappelet, J.-L., Janssen, M., Scholl, H.J. (eds.) EGOV 2010. LNCS, vol. 6228, pp. 5060. Springer, Heidelberg (2010)

7. Espinoza, J.F., Recinos, I.P., Morales, M.P.: Datos Abiertos: oportunidades y desafíos para Centroamérica con base en una cadena de valor. In: Conferencia Regional de Datos Abiertos para América Latina y el Caribe - 2013 - Montevideo, Uruguay (2013)

8. Grandori, A.: An organizational assessment of interfirm coordination modes. Organization Studies 18(6), 897-925 (1997)

9. Helbig, N., Cresswell, A.M., Burke, B.G., Pardo, T.A., Reyes-Luna, L.: Modeling the Informational Relationships between Government and Society. In: Open Government Consultative Workshop, June 26-27. CTG, Albany (2012)

10. Helbig, N., Cresswell, A.M., Burke, B.G., Reyes-Luna, L.: The Dynamics of Opening Government Data (2013),

http: / / www.ctg.albany.edu/publications / reports / opendata/ opendata.pdf (acessojaneiro 2013)

11. Hughes, J.: Why Open Data is necessary but not sufficient to make a difference (2011), http: //www.slideshare.net/janet-hughes /

how-to-make-the-flowers-bloom

12. Janssen, M., Charalabidis, Y., Zuiderwijk, A.: Benefits, Adoption Barriers and Myths of Open Dataand Open Government. Information Systems Management 29, 258-268 (2012)

13. Kalampokis, E., Tambouris, E., Tarabanis, K.: A classification scheme for open government data: towards linking decentralised data. 266 Int. J. Web Engineering and Technology 6(3) (2011)

14. Lathrop, D., Ruma, L.: Open Government: Collaboration, Transparency, and Participation in Practice, 1st edn. O'Reilly Media (2010)

15. McKinsey, Open data: Unlocking innovation and performance with liquid information (2013), http://www.mckinsey.com/insights/business_technology/ open_data_unlocking_innovation_and_performance_with_liquid_i nformation (access in November 2013)

16. Oliver, C.: Determinants of interorganizational relationships: integration and future directions. Academy of Management Review 15, 241-265 (1990)

17. Prince, A., Jolías, L., Brys, C.: Análisis de La cadena de valor del ecosistema de Datos Abiertos de La Ciudad de Buenos Aires. In: Conferencia Regional de Datos Abiertos para América Latina y el Caribe - junio de 2013 - Montevideo, Uruguay (2013), http: / /www.princeconsulting.biz/pdf / 7 .pdf (accessed August 2013)

18. Robinson, D., Zeller, W., Yu, D.: Government data and the invisible hand. Yale Journal of Law and Technology 11, 160 (2009)

19. Sayogo, D.G., Pardo, T.: Exploring the Motive for Data Publication in Open Data Initiative: Linking Intention to Action. In: 45th Hawaii International Conference on System Sciences (2012),

http: / /www.ctg.albany.edu/publications / journals / hicss_2012_datasharing (acesso em dezembro 2012)

20. Solar, M., Concha, G., Meijueiro, L.: A Model to Assess Open Government Data in Public Agencies. In: Scholl, H.J., Janssen, M., Wimmer, M.A., Moe, C.E., Flak, L.S. (eds.) EGOV 2012. LNCS, vol. 7443, pp. 210-221. Springer, Heidelberg (2012)

21. W3C. The Open data Handbook, http://opendatamanual .org (2009) (accessed September 2011) 
22. Williamson, O.E.: The Economics of Governance. The American Economic Review 95(2), $1-18(2005)$

23. Zuiderwijk, A., Janssen, M., Choenni, S., Meijer, R., Alibaks, R.S.: Socio-technical Impediments of Open Data. Journal of e-Government 10(2), 156-172 (2012), http: / /www.ejeg.com; ISSN 1479-439X 156 (Academic Publishing International Ltd Zuiderwijk 